Journal of Agricultural Sciences
(Tarim Bilimleri Dergisi)

\title{
Effects of Different Milk-Tube Guidance Settings and Teat-Cup Types on the Dynamics of Teat-End Vacuum and Vacuum Fluctuations During Machine Milking
}

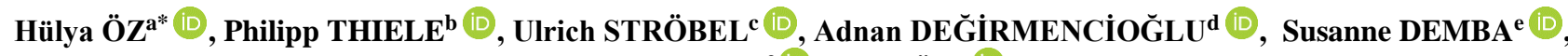 \\ Sandra ROSE ${ }^{\text {(D) }}$, Erdal ÖZ ${ }^{\text {(iD }}$ \\ ${ }^{a}$ Ege University, Ege Vocational Training School, Bornova-Izmir, TURKIYE

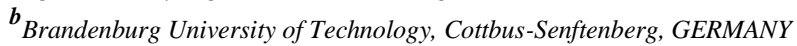 \\ ${ }^{c}$ Landesanstalt für Landwirtschaft, Ernährung und Ländlichen Raum (LEL), GERMANY

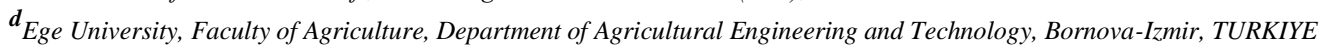

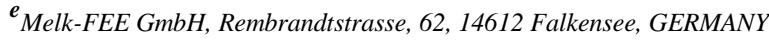

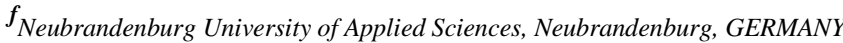

ARTICLE INFO

Research Article

Corresponding Author: Hülya ÖZ, E-mail: hulya.oz@ege.edu.tr

Received: 2 June 2020/ Revised: 4 December 2020 / Accepted: 7 December 2020 / Online: 20 January 2022

\section{ABSTRACT}

The objective of this study was to determine the effects of milk tube guidance setting and teat cup type on the dynamics of teat-end vacuum and vacuum fluctuations in quarter individual milking systems. In order to meet this objective, a series of wet tests was conducted in the laboratory. Different teat cups; AMS, BIO and RVS along with the milk tube guidance settings namely; direct tube, half-half tube and Y-piece tube system with varying tube inside diameters were tested at different water flow rates. The data obtained from the wet-test measurements were used to calculate the teat-end vacuum and vacuum fluctuation at the teatend in $b$ and $d$ - phase.

From the study conducted, it was found that the teat-end vacuum in $\mathrm{BIO}$ is always between the range of 32 and $42 \mathrm{kPa}$ as recommended by
DIN ISO 5707 (2010a) at any flow rate for all three types of connections. The teat-end vacuum for RVS was between $32-42 \mathrm{kPa}$ range if the flow rate varies between 4 and $6 \mathrm{~L} \mathrm{~min}^{-1}$ for both, the direct and the half-half connection. The Y-piece connection meets DIN ISO 5707 (2010a) requirements once the flow rate changes between 2 and $6 \mathrm{~L} \mathrm{~min}^{-1}$. The findings about milk tube inside diameter indicated that the use of 14 or 16 $\mathrm{mm}$ milk tube diameter for $\mathrm{BIO}$ will provide better teat-end vacuum if the recommended value of $10 \mathrm{~mm}$ is used. On the other hand, the use of 16 $\mathrm{mm}$ milk tube diameter was found to be appropriate for AMS as recommended by the manufacturer. For the RVS, the appropriate milk tube diameter should be $14 \mathrm{~mm}$ when statistical differences in $\mathrm{b}$ and $\mathrm{d}$ phase are examined from the point of teat-end vacuum and vacuum fluctuations.

Keywords: Vacuum drops, Teat-end vacuum, Vacuum fluctuation, Quarter individual milking

(C) Ankara University, Faculty of Agriculture

\section{Introduction}

During the whole milking process, the udder is highly stressed. Therefore, the large-area spread of milking plants, number of udder diseases have strongly increased (Graff 2005). The modern milking technique is very concerned to work as animal-friendly as possible but nevertheless the damage and involved diseases of the udder cannot be completely eliminated.

The teat cup liner is of importance since it comes contact with the cow's teat. As a result of this, milking performance, udder and teat health are higly affected. Bobić et al. (2018) worked on two different teat cup liners (different head diameter, length, body shape) with or without air vent. They investigated their efffects on teat condition score, somatic cell count. The results obtained from the study as a comparison with the control group indicated that teat cup liner type affetcs teat skin condition, somatic cell count, and therefore the risk of mastitis.

Ströbel et al. (2011) investigated the teat end vacuum condition in different automatic milking systems. For this purpose, three different milking systems were tested. Two of these systems had individually guided milk tubes. The teat cups of each system were constructed with air inlet at the end of each teat cup that allowed air entry into the milk tube.

In another study, Ströbel (2012) developed a vacuum control system for the teat-end vacuum. The concept for the vacuum control system indicated that it is possible to reduce the mean teat-end milking vacuum in the suction phase to $20 \mathrm{kPa}$ at a flow rate of $0.25 \mathrm{~L} \mathrm{~min}^{-1}$ per udder quarter. At higher flow rates of $1.5 \mathrm{~L} \mathrm{~min}^{-1}$ and more per udder quarter, the teat-end vacuum is 
similar to the machine vacuum with a mean value of approximately $30 \mathrm{kPa}$. Therefore, supplying a high teat-end vacuum at a high and a low teat-end vacuum at low milk flow rates was possible.

DIN ISO 5707 (2010a) indicates that a mean liner vacuum within the range $32 \mathrm{kPa}$ to $42 \mathrm{kPa}$ during the peak low period of milking for cows ensures that most cows will be milked quickly, gently and completely. Besier et al. (2016) additionally implied that this range of vacuum pressure is adequate for liner movement and a sufficient pressure on the teat can be provided during the massage d-phase. Besier et al. also mentioned that the teat-end vacuum should not be much higher than $42 \mathrm{kPa}$ as it can cause damage of teat tissue mainly during periods of low milk. As a concluding remark, they stated that the most of the literature used in their review paper was from the 1960s, 1970s or 1980s, since there is no newer study and Thus, it is necessary to conduct new studies on the influence of vacuum drops and fluctuations.

Vacuum fluctuations can occur cyclic, irregular or in combination (Nyhan 1968; Tolle et al. 1977). Cyclic vacuum fluctuations occur in regular intervals during milking and the main reason is the liner movement and milk flow (Thiel et al. 1973) and this leads, due to a loss of flow, to a vacuum decline at the teat-end (Ordolff 1991; Mein 1992). On the other hand, irregular fluctuations are caused by liner slips, cluster changing or cluster fall off during milking and unplanned air admission into the vacuum system (Nyhan 1968; Thiel et al. 1973). If vacuum fluctuations occur in combination of irregular and cyclic form for a long milking duration, the risk for congestion of the teat tissue along with new infections was found to be increased (O'Callaghan et al. 1976; O'Shea et al. 1976). In this perspective, it is obvious that vacuum conditions at the teat-end are of importance to investigate in terms of for milking techniques and especially in quarter individual systems. It is important to determine the effects of different combination of teat-cups and milk tube connection alternatives in order to obtain the most stable and safe vacuum conditions at the teat-end. Hence, a study was conducted and the objective of this study was to determine the effects of milk tube guidance settings and different teat cup type on the dynamics of teat-end vacuum and vacuum fluctuations in quarter individual milking systems.

\section{Material and Methods}

The milking-system itself is a part of the laboratory milking parlour at Leibniz-Institut für Agrartechnik und Bioökonomie e.V. (ATB), Potsdam-Berlin/Germany. Figure 1 shows the set-up of the milking parlour laboratory which is basically a part of a conventional herringbone parlour. The wet-measurement-method as described in DIN ISO 6690 (2010b) was followed during the experiments and water that simulates milk flow was used during the measurements. The vacuum was measured at different locations in a milking-system with variable set-up in order to compare the vacuum behaviour of various milk tube and teat cup combinations. The different teat cup types are alternately, of four pieces each, clamped into the holder and in that way brought to udder level. Each artificial teat was placed into a teat cup and connected to a separate flow meter. The range and accuracy of each flow meter were 0.2 to $2.0 \mathrm{~L} \mathrm{~min}^{-1}$ per quarter and $\pm 2 \%$. The sequential pulsation applied with the rate of $60 \mathrm{~min}^{-1}$ and the ratio of and 65:35, and these values were kept constant during the experiments. The vacuum pump of the experimental milking system was oil lubricated type with the capacity of 8001 at $50 \mathrm{kPa}$. Three different teat cups were used alternatively for the experiments and the basic specifications are tabulated in Table 1. Each teat cup was tested at a vacuum level as recommended by manufacturers.

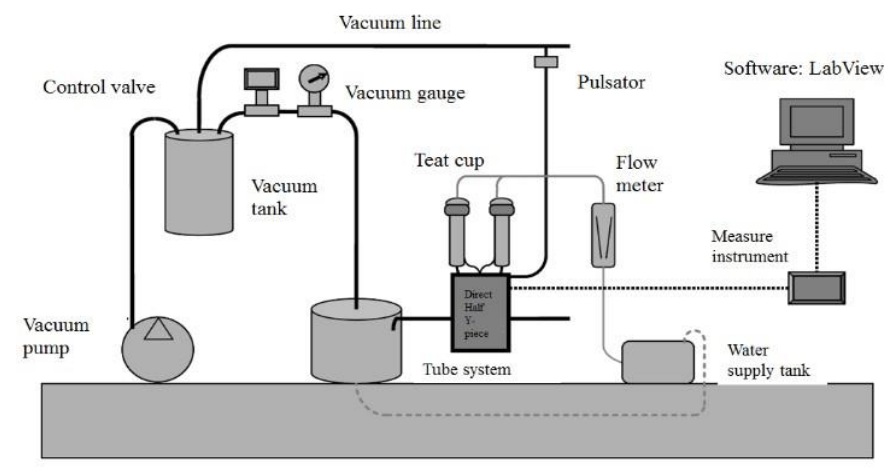

Figure 1- Schematic drawing of the laboratory milking parlor with connected milking-system (Rose 2006)

The BIOж teat cup consists of a silicon liner and is equipped with a periodic air inlet beneath the teat. Through pulse-cycle related rhythmic opening and closing of a valve the vacuum in the suction phase should be kept stable and as low as possible in the relief phase.

The $\mathrm{RVS}^{*}$ teat cup liner is made of rubber. It has a constant and permanent air inlet above the teat. In contrast to the BIO teat cup, the air is inset at every suction phase as periodic air inlet to promote the milk flow. The AMS* teat cup uses a pulse independent and constantly disposable air inlet beneath the udder. 
During the experimental procedure three different tube connection systems were used as depicted in Figure 2. These tube connections were the direct tube, half-half and Y-piece tube. These tube connections were designed and manufactured at ATB.

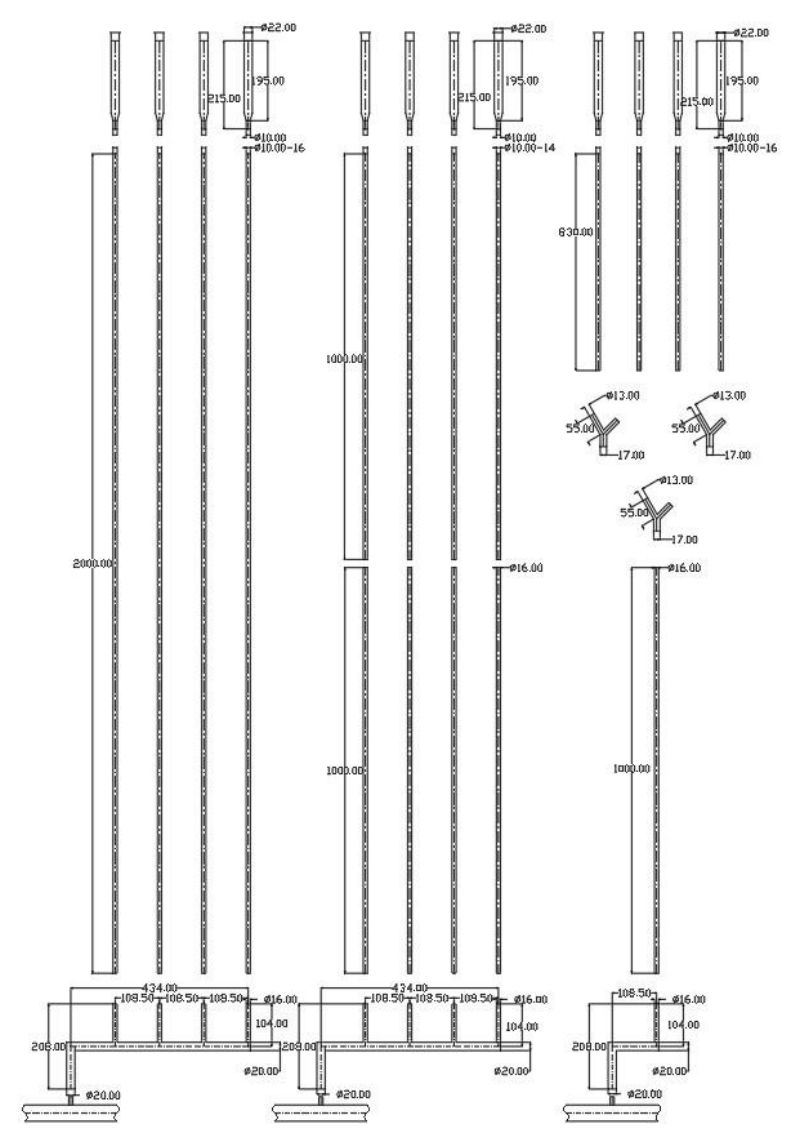

Figure 2- Technical drawing of the milk tube guidance settings. Direct tube system (left), Half-half tube system (middle), Ypiece tube system (right)

The simplest type is the direct tube guidance setting. In this type, teat cups are directly connected to the collecting piece by $2 \mathrm{~m}$ long tubes.

The half-half tube system consists two tubes, each $1 \mathrm{~m}$ long per cup at different tube inside diameters. The lower tube that is closer to the collecting piece is not modified during the whole test series and always has a tube inside diameter of $16 \mathrm{~mm}$. If the upper part of the tube had a tube inside diameter of $16 \mathrm{~mm}$ as well, the experimental setup would be similar to the one of the direct tube system with $16 \mathrm{~mm}$ tube inside diameter. For this reason, only two tube inside diameters were tested for this tube guidance setting. The third set-up type uses special Y-pieces that bring together all four milk flows following $1 \mathrm{~m}$ long tube. Therefore, there is no collecting piece in this tube system.

The half-half tube system consists of two tubes, each one-meter-long at different inside diameters (e.g. $14 \mathrm{~mm}$ ) for each teat cup. The lower tube that is closer to the collecting piece is not modified during the whole test series and always has a tube inside diameter of $16 \mathrm{~mm}$. If the higher tube had a tube inside diameter of $16 \mathrm{~mm}$ as well, the experimental setup would be similar to the one of the direct tube system with $16 \mathrm{~mm}$ tube inside diameter. For this reason, only two different inside diameters were tested for this tube guidance setting. The third set-up type uses special Y-pieces so that all four milk flows merges after $1 \mathrm{~m}$ long tube with $16 \mathrm{~mm}$ inside diameter. To measure the vacuum levels in different location of the milking system four absolute pressure sensors manufactured by Keller Druckmesstechnik GmbH individually placed in a T-form test case made of brass and this $\mathrm{T}$ formed pieces were used the sensors to the milk and pulse tubes precisely. Accuracy of the sensor used was $\pm 0,5 \%$ and the maximum measurement frequency is $2 \mathrm{kHz}$. The sensors were directly connected to the A/D converter which transmitted the analog signals of the sensors to digital form and send them to the computer. The measurement rate adjusted to $500 \mathrm{~Hz}$ during the experiments. The data was stored in the computer with LabView software.

For each milk tube and teat cup combination tested at total flow rate ranging between 2 and $6 \mathrm{~L} \mathrm{~min}^{-1}\left(0.5\right.$ and $1.5 \mathrm{~L} \mathrm{~min}^{-1}$ per quarter). Three replications were achieved for each experiment and each measurement lasted 60 seconds and the data was consequently recorded every $2 \mathrm{msec}$ with a measurement frequency of $500 \mathrm{~Hz}$. 
The first five measured pulse cycles were determined before every experimental procedure for the analysis of pulse progressions written as macro and evaluated as recommended by the DIN ISO standard (DIN ISO 6690, 2010b). At the same time, each of these five cycles was subdivided into its single pulse phases and the run-time was determined.

Furthermore, the vacuum fluctuations in each cycle were calculated. To estimate the fluctuation, the difference between the highest and the lowest value of every phase was identified as indicated in Equation 1. The results were averaged as well, so that a fluctuation value for the b- and d-phase was existent (DIN ISO 6690, 2010b).

$V S_{p}=\frac{1}{n} \sum_{i=1}^{n}\left(V P \max _{i}-V P \min _{i}\right)$

Where; $\mathrm{VS}_{\mathrm{p}}$ is Vacuum fluctuation of the phase; $\mathrm{VP}_{\max }$ is Maximum pressure in the pulse phase; $\mathrm{VP}_{\min }$ is Minimum pressure in the pulse phase; $n$ is Number of the consecutive pulse cycles $(n=5)$

The collected data with the help of software from LabView were transferred to SPSS $®$ for the variance analysis and the Duncan's multiple range tests.

\section{Results and Discussion}

The data obtained from the experiments were evaluated based on ISO recommendation and the results are depicted for a direct tube connection in Figure 3, a half-half connection in Figure 4, y-piece connection in Figure 5 for three different milk tube diameters along with three different teat cups at different flow rates in b-phase. There are some common points in these three figures. One of them is that the general trend is the same even though the milk tube connection type is different. The teat-end vacuum in BIO teat cup is always between the range of 32 and $42 \mathrm{kPa}$ at any flow and for all three types of connections. For RVS teat cup, the teat-end vacuum is between 32-42 $\mathrm{kPa}$ range if the flow rate varies between 4 and $6 \mathrm{~L} \mathrm{~min}^{-1}$ for both direct and half-half connection while Y-piece connection meets ISO requirements if the flow rate between 2 and $6 \mathrm{~L}^{-1}$. The trend in terms of teat-end vacuum for AMS is similar for all three types of connections. Only the flow rate that provides $32-42 \mathrm{kPa}$ teat-end vacuum is $2 \mathrm{~L} \mathrm{~min}^{-1}$ for direct tube and half and half connection. On the other hand, once the milk flow starts, the teatend vacuum for AMS is beyond the recommended range by ISO if Y-piece connection is used at any diameter except $2 \mathrm{~L}_{\text {min }}{ }^{-1}$ flow rate and at a diameter of $10 \mathrm{~mm}$. The results from variance analysis carried out in $\mathrm{b}$ and d-phase for both, teat-end vacuum and fluctuations are as follows:

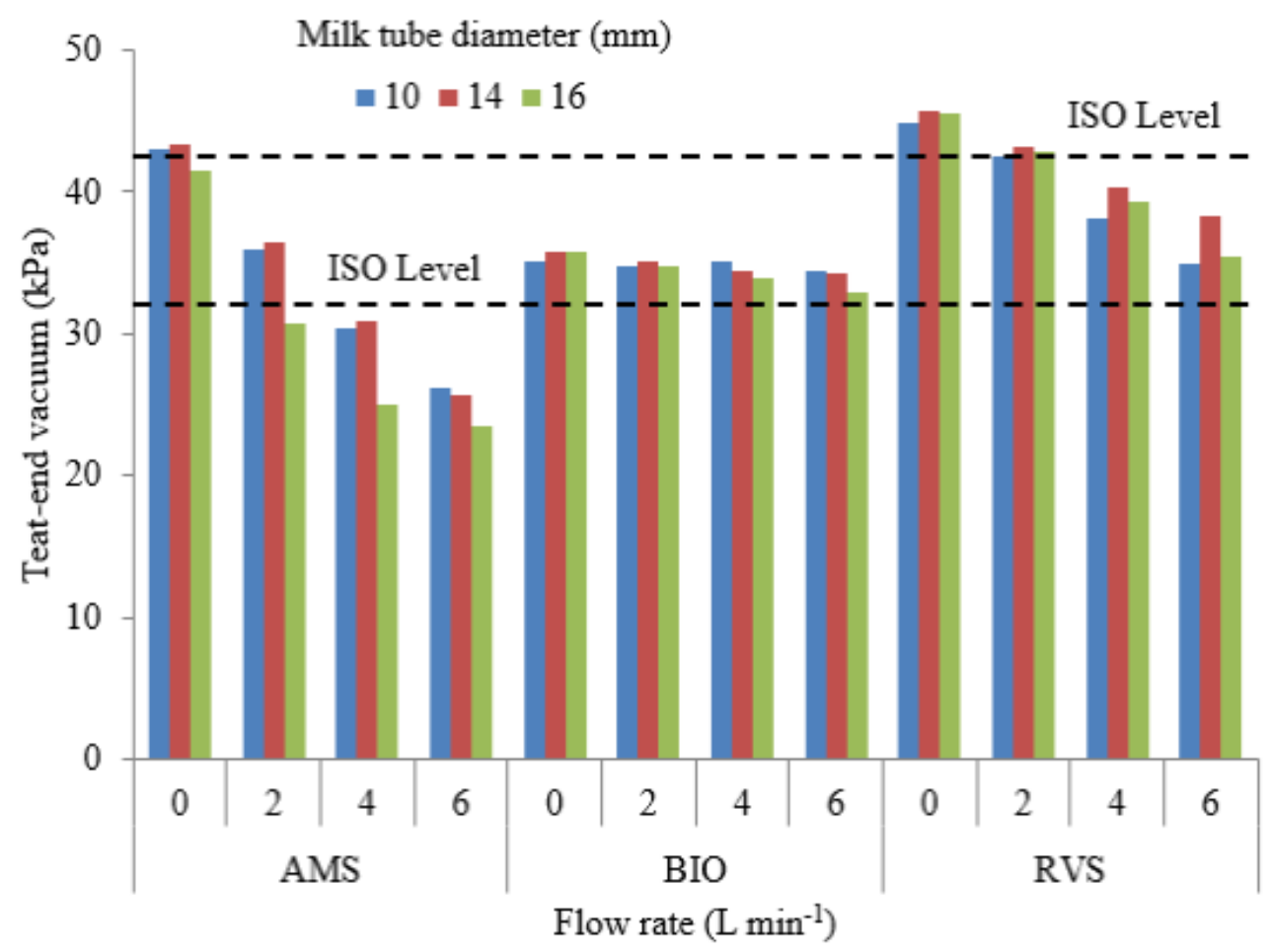

Figure 3- Effects of different flow rate and milk tube diameter on teat-end vacuum in different teat cups with a direct tube connection in b-phase 


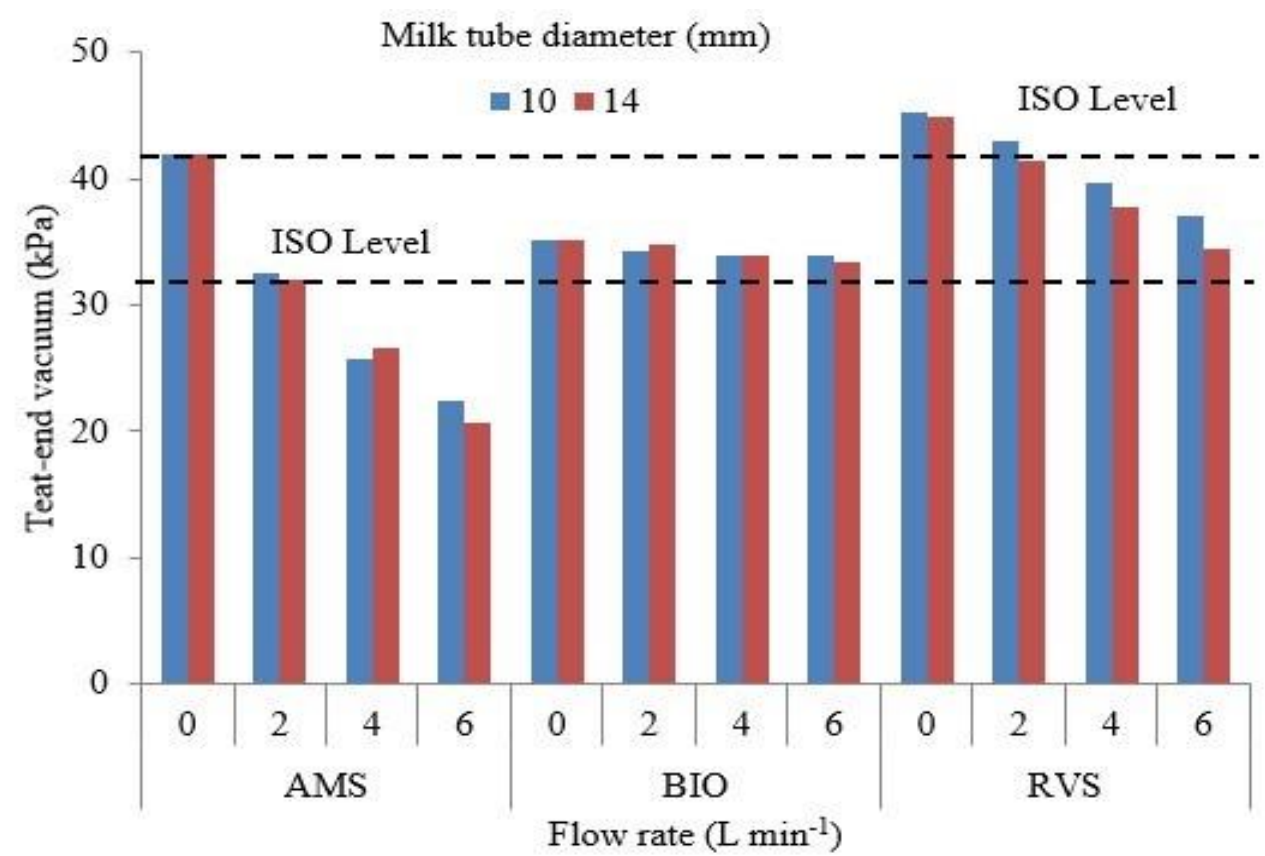

Figure 4- Effects of flow rate and milk tube diameter on teat-end vacuum in different teat cups with half-half connection in b-phase

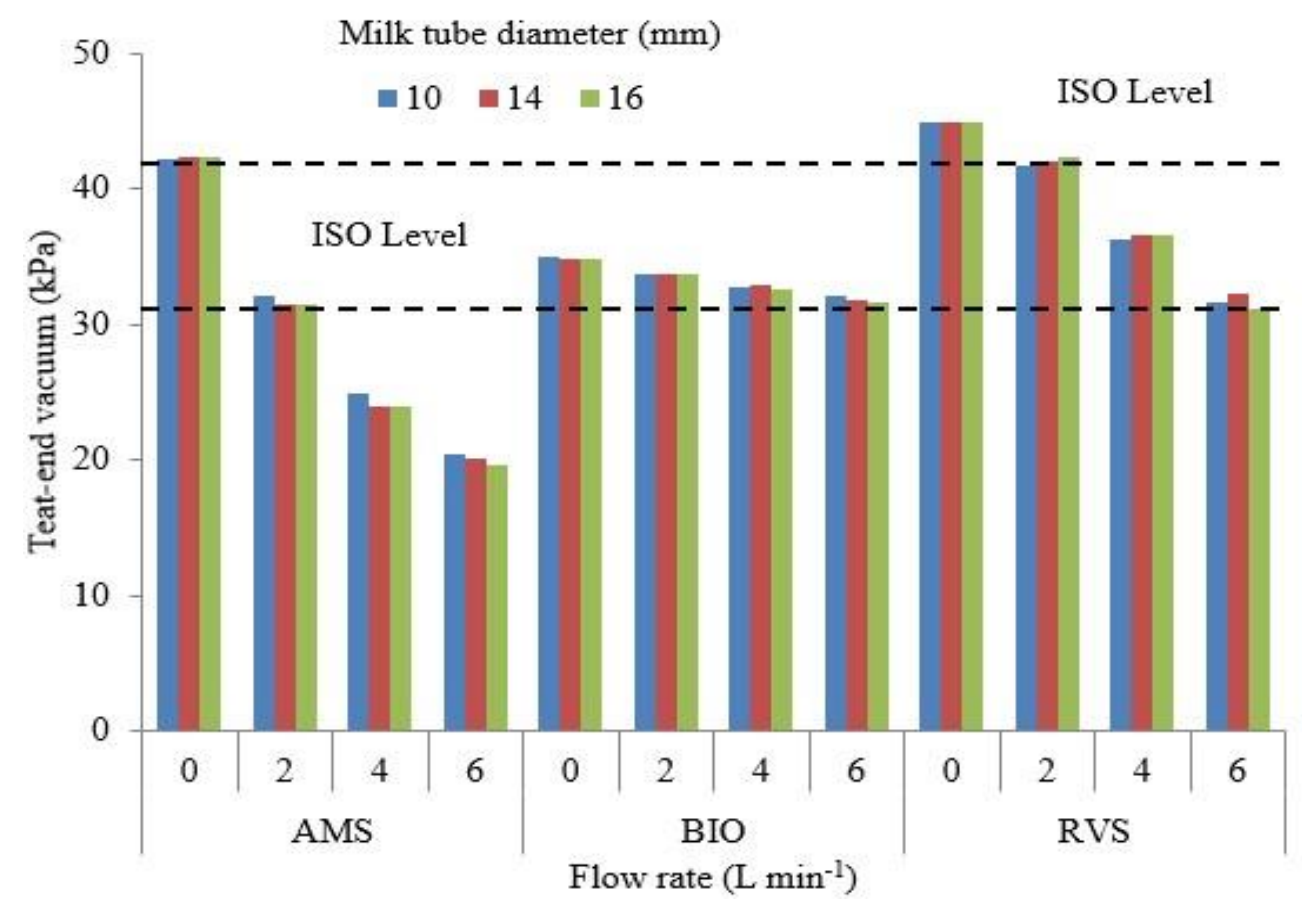

Figure 5- Effects of flow rate and milk tube diameter on teat-end vacuum in different teat cups with Y-piece connection in bphase

The data collected for each milking system were not evaluated in the same pool, but separately since the recommended milking vacuum by the manufacturer for BIO was $35 \mathrm{kPa}$ and the milk tube inside diameter was $10 \mathrm{~mm}$ while the recommend milking vacuum and milk tube diameter by the manufacturer was the same for AMS and RVS ( $45 \mathrm{kPa}$ and $16 \mathrm{~mm}$, respectively). The results from the analysis of teat-end vacuum in $b$ and d-phase are tabulated in Table 2. As seen from the table, the main effect of tube connection type (direct, half-half and Y piece) along with flow rate and milk tube inside diameter and most of their possible (double and triple) interactions are significant at a probability level of $95 \%$. Only the insignificant main effect is the diameter effect for AMS while triple interaction of TC $x$ FR $x$ DIA for BIO in b-phase and for RVS in d-phase are also insignificant at a probability level of $95 \%$. 
Table 1- Basic Specifications of the teat cups used in this study

\begin{tabular}{ccccc}
\hline $\begin{array}{c}\text { Teat } \\
\text { cup }\end{array}$ & $\begin{array}{c}\text { Milking } \\
\text { vacuum }\end{array}$ & $\begin{array}{c}\text { Liner } \\
\text { material }\end{array}$ & Air inlet & $\begin{array}{c}\text { Milk tube inside } \\
\text { diameter }^{\Psi}\end{array}$ \\
\hline AMS & $45 \mathrm{kPa}$ & Rubber & Free air inlet beneath the teat & $16 \mathrm{~mm}$ \\
BIO & $35 \mathrm{kPa}$ & Silicon & Periodic air inlet beneath the teat & $10 \mathrm{~mm}$ \\
RVS & $45 \mathrm{kPa}$ & Rubber & Periodic air inlet at mouthpiece & $16 \mathrm{~mm}$ \\
\hline
\end{tabular}

$£$ : Recommended milking vacuum and $\Psi$ : recommended milk tube diameter by the manufacturers

Table 2- The results from variance analysis for the teat-end vacuum in b and d-phase in different milking systems

\begin{tabular}{|c|c|c|c|c|c|c|c|}
\hline \multirow{3}{*}{ Factors } & & \multicolumn{6}{|c|}{$F$-value ( $P$ value $)$} \\
\hline & & \multicolumn{3}{|c|}{ Teat-end vacuum in b-phase } & \multicolumn{3}{|c|}{ Teat-end vacuum in d-phase } \\
\hline & & $A M S$ & $\mathrm{BIO}$ & $R V S$ & $A M S$ & $B I O$ & $R V S$ \\
\hline Tube conn.(Tc) & 2 & $\begin{array}{c}94.52 \\
(<0.001)\end{array}$ & $\begin{array}{c}189.26 \\
(<0.001)\end{array}$ & $\begin{array}{c}137.71 \\
(<0.001)\end{array}$ & $\begin{array}{c}54.22 \\
(<0.001) \\
\end{array}$ & $\begin{array}{c}163.23 \\
(<0.001)\end{array}$ & $\begin{array}{c}93.14 \\
(<0.001)\end{array}$ \\
\hline Flow rate $(\mathrm{Fr})$ & 3 & $\begin{array}{l}1651.77 \\
(<0.001) \\
\end{array}$ & $\begin{array}{c}240.87 \\
(<0.001) \\
\end{array}$ & $\begin{array}{l}1032.14 \\
(<0.001)\end{array}$ & $\begin{array}{l}1292.39 \\
(<0.001) \\
\end{array}$ & $\begin{array}{l}1186.37 \\
(<0.001)\end{array}$ & $\begin{array}{l}1407.73 \\
(<0.001) \\
\end{array}$ \\
\hline Diameter (Dia) & 2 & $\begin{array}{c}0.32 \\
(0.721)\end{array}$ & $\begin{array}{c}6.23 \\
(<0.001)\end{array}$ & $\begin{array}{c}113.65 \\
(<0.001)\end{array}$ & $\begin{array}{c}33.61 \\
(<0.001)\end{array}$ & $\begin{array}{c}597.03 \\
(<0.001)\end{array}$ & $\begin{array}{c}8.65 \\
(<0.001)\end{array}$ \\
\hline $\mathrm{Tc} \times \mathrm{Fr}$ & 6 & $\begin{array}{c}27.84 \\
(<0.001) \\
\end{array}$ & $\begin{array}{c}8.76 \\
(<0.001) \\
\end{array}$ & $\begin{array}{c}38.13 \\
(<0.001) \\
\end{array}$ & $\begin{array}{c}9.83 \\
(<0.001) \\
\end{array}$ & $\begin{array}{c}13.68 \\
(<0.001) \\
\end{array}$ & $\begin{array}{c}12.65 \\
(<0.001) \\
\end{array}$ \\
\hline Tc x Dia & 4 & $\begin{array}{c}58.97 \\
(<0.001) \\
\end{array}$ & $\begin{array}{c}3.80 \\
(0.007) \\
\end{array}$ & $\begin{array}{c}113.98 \\
(<0.001) \\
\end{array}$ & $\begin{array}{c}9.48 \\
(<0.001) \\
\end{array}$ & $\begin{array}{c}123.78 \\
(<0.001) \\
\end{array}$ & $\begin{array}{c}3.11 \\
(<0.001) \\
\end{array}$ \\
\hline FR x Dia & 6 & $\begin{array}{c}16.49 \\
(<0.001) \\
\end{array}$ & $\begin{array}{c}8.13 \\
(<0.001) \\
\end{array}$ & $\begin{array}{c}3.50 \\
(0.004) \\
\end{array}$ & $\begin{array}{c}8.64 \\
(<0.001) \\
\end{array}$ & $\begin{array}{c}110.70 \\
(<0.001)\end{array}$ & $\begin{array}{c}3.08 \\
(0.010) \\
\end{array}$ \\
\hline Tc x Fr x Dia & 12 & $\begin{array}{c}23.52 \\
(<0.001) \\
\end{array}$ & $\begin{array}{c}2.13 \\
(0.025) \\
\end{array}$ & $\begin{array}{c}9.62 \\
(<0.001) \\
\end{array}$ & $\begin{array}{c}2.28 \\
(0.016) \\
\end{array}$ & $\begin{array}{c}13.72 \\
(<0.001) \\
\end{array}$ & $\begin{array}{c}0.90 \\
(0.551) \\
\end{array}$ \\
\hline Error & 72 & & & & & & \\
\hline Total & 108 & & & & & & \\
\hline
\end{tabular}

The results from the variance analysis as a consequence of 108 data evaluation for the vacuum fluctuations as it was the case for the teat-end vacuum are given in Table 3. As an opposite of teat-end vacuum evaluations, there are many insignificant factors that affect vacuum fluctuations in different milking systems. As the main factors, the effects of tube connection type and flow rate on vacuum fluctuations are significant if significance level of $\mathrm{P}$ is considered to be $95 \%$ except the tube connection type for $\mathrm{BIO}$ in d-phase. This means that the tube connection type for BIO does not affect the vacuum fluctuations in d-phase. Once the results are evaluated in terms of the effect of milk tube inside diameter, it can be said that the changes in diameter only affect the vacuum fluctuation in d-phase for both, AMS and BIO. The effects of milk tube inside diameter on vacuum fluctuations in bphase for all milking systems along with the one in d-phase for RVS. The effects of double interactions of tube connection type and flow rate diameter is significant at a probability level of $95 \%$ except the tube connection and diameter interaction for BIO in b-phase. On the other hand, flow rate and diameter interaction is only significant in d-phase for two milking systems. The triple interaction of the factors is only significant in b-phase for AMS and RVS but it is only significant for BIO in d-phase at a probability level of $95 \%$. The results obtained from the Duncan's multiple range tests for the main factors are tabulated in Table 4 throught Table 9. 
Table 3- The results from variance analysis for the vacuum fluctuations in b and d-phase in different milking systems

\begin{tabular}{|c|c|c|c|c|c|c|c|}
\hline \multirow{3}{*}{ Factors } & \multirow{3}{*}{$d f$} & \multicolumn{6}{|c|}{$F$-value (P value) } \\
\hline & & \multicolumn{3}{|c|}{ Vacuum fluctuation in b-phase } & \multicolumn{3}{|c|}{ Vacuum fluctuation in d-phase } \\
\hline & & $A M S$ & $B I O$ & $R V S$ & $A M S$ & $B I O$ & $R V S$ \\
\hline Tube conn. (Tc) & 2 & $\begin{array}{c}15.49 \\
(<0.001)\end{array}$ & $\begin{array}{c}65.96 \\
(<0.001)\end{array}$ & $\begin{array}{c}6.16 \\
(0.003)\end{array}$ & $\begin{array}{c}40.11 \\
(<0.001)\end{array}$ & $\begin{array}{c}1.806 \\
(0.172)\end{array}$ & $\begin{array}{c}7.704 \\
(<0.001)\end{array}$ \\
\hline Flow rate $(\mathrm{Fr})$ & 3 & $\begin{array}{c}386.51 \\
(<0.001)\end{array}$ & $\begin{array}{c}594.54 \\
(<0.001)\end{array}$ & $\begin{array}{c}451.10 \\
(<0.001)\end{array}$ & $\begin{array}{c}343.87 \\
(<0.001)\end{array}$ & $\begin{array}{c}250.16 \\
(<0.001)\end{array}$ & $\begin{array}{c}314.94 \\
(<0.001)\end{array}$ \\
\hline Diameter (Dia) & 2 & $\begin{array}{c}13.57 \\
(0.721) \\
\end{array}$ & $\begin{array}{c}1.09 \\
(0.340) \\
\end{array}$ & $\begin{array}{c}0.076 \\
(0.926) \\
\end{array}$ & $\begin{array}{c}6.137 \\
(0.003) \\
\end{array}$ & $\begin{array}{c}217.08 \\
(<0.001)\end{array}$ & $\begin{array}{c}0.994 \\
(0.375) \\
\end{array}$ \\
\hline $\mathrm{Tc} \times \mathrm{Fr}$ & 6 & $\begin{array}{c}3.71 \\
(0.003)\end{array}$ & $\begin{array}{c}4.91 \\
(<0.001) \\
\end{array}$ & $\begin{array}{c}2.429 \\
(0.034) \\
\end{array}$ & $\begin{array}{c}5.92 \\
(<0.001)\end{array}$ & $\begin{array}{c}10.08 \\
(<0.001)\end{array}$ & $\begin{array}{c}4.08 \\
(0.001) \\
\end{array}$ \\
\hline Tc x Dia & 4 & $\begin{array}{c}2.59 \\
(0.043) \\
\end{array}$ & $\begin{array}{c}2.13 \\
(0.086) \\
\end{array}$ & $\begin{array}{c}2.014 \\
(0.101) \\
\end{array}$ & $\begin{array}{c}2.53 \\
(0.047) \\
\end{array}$ & $\begin{array}{c}13.15 \\
(<0.001) \\
\end{array}$ & $\begin{array}{c}2.52 \\
(0.048) \\
\end{array}$ \\
\hline Fr x Dia & 6 & $\begin{array}{c}1.21 \\
(0.308)\end{array}$ & $\begin{array}{c}0.92 \\
(0.482)\end{array}$ & $\begin{array}{c}0.624 \\
(0.710)\end{array}$ & $\begin{array}{c}6.53 \\
(<0.001)\end{array}$ & $\begin{array}{c}26.49 \\
(<0.001)\end{array}$ & $\begin{array}{c}2.78 \\
(0.017)\end{array}$ \\
\hline Tc $x$ Fr $x$ Dia & 12 & $\begin{array}{c}0.718 \\
(0.729)\end{array}$ & $\begin{array}{c}3.21 \\
(0.001)\end{array}$ & $\begin{array}{c}2.386 \\
(0.012)\end{array}$ & $\begin{array}{c}1.51 \\
(0.138)\end{array}$ & $\begin{array}{c}13.54 \\
(<0.001)\end{array}$ & $\begin{array}{c}1.51 \\
(0.140)\end{array}$ \\
\hline Error & 72 & & & & & & \\
\hline Total & 108 & & & & & & \\
\hline
\end{tabular}

Table 4- The Duncan's multiple range test results ${ }^{\zeta}$ for the effect of tube connection type on teat-end vacuum (kPa) in b and dphase in different milking systems

\begin{tabular}{ccccccc}
\hline \multirow{2}{*}{ Tube connection type } & \multicolumn{3}{c}{ Teat-end vacuum in b-phase } & \multicolumn{2}{c}{ Teat-end vacuum in d-phase } \\
\cline { 2 - 7 } & $A M S$ & $B I O$ & $R V S$ & $A M S$ & $B I O$ & $R V S$ \\
\hline YP & $29.54^{\mathrm{a}}$ & $33.29^{\mathrm{A}}$ & $38.75^{\mathrm{a}^{\mathrm{a}}}$ & $28.08^{\mathrm{d}}$ & $30.50^{\mathrm{D}}$ & $37.76^{\mathrm{d}^{\prime}}$ \\
HH & $31.73^{\mathrm{b}}$ & $34.30^{\mathrm{B}}$ & $38.41^{\mathrm{b}^{\mathrm{b}}}$ & $29.23^{\mathrm{e}}$ & $31.46^{\mathrm{E}}$ & $39.66^{\mathrm{e}^{\prime}}$ \\
DT & $32.74^{\mathrm{c}}$ & $34.71^{\mathrm{C}}$ & $40.94^{\mathrm{c}^{\mathrm{c}}}$ & $31.53^{\mathrm{f}}$ & $32.62^{\mathrm{F}}$ & $40.03^{\mathrm{f}}$ \\
\hline
\end{tabular}

ร: Means with the same letter in the same column are not significantly different from each other for each column. YP: Y piece; HH: half-half and DT: direct tube connection. The gray shaded cells are the ones within the recommended range of $32-42 \mathrm{kPa}$ by DIN ISO 5707

As seen from Table 4, the effect of tube connection type is significant for all milking systems considered in this study in both, $\mathrm{b}$ and d-phase in terms of teat-end vacuum. When the results were examined, it is seen that the teat-end vacuum in b-phase is within the 32-42 kPa range except for AMS when YP and HH connection types. For both types, the teat-end vacuum is lower than $32 \mathrm{kPa}$. It is also interesting to see that the direct tube connection provides the highest teat-end vacuum values for all milking systems in b-phase. This means that the lowest vacuum drops occur for all three milking systems and three connections. The reason for this can be attributed to the fact that $\mathrm{HH}$ and YP connection types require interim connection parts and milk tube diameter change between 10-16 mm. On the other hand, for DT tube connection, there is no interim part and tube is a single piece at a certain diameter and it is directly connected to the main milk line. This causes less frictional forces and vacuum with a lower loss affects teat-end. It could be also stated that the flow characteristics for all connection types change for three different milking system.

The effect of flow rate on teat-end vacuum in $b$ and d-phase are tabulated in Table 5. The trend in teat-end vacuum for all milking systems in $b$ and d-phase is the same. The teat-end vacuum goes down as the flow rate increases and the differences in each column for the same teat cup are significant in all cases.

Table 5- The Duncan's multiple range test results ${ }^{\zeta}$ for the effect of flow rate on teat-end vacuum (kPa) in $b$ and d-phase in different milking systems

\begin{tabular}{ccccccc}
\hline \multirow{2}{*}{ Flow rate $\left(\right.$ L min $\left.^{-1}\right)$} & \multicolumn{2}{c}{ Teat-end vacuum in b-phase } & \multicolumn{2}{c}{ Teat-end vacuum in d-phase } \\
\cline { 2 - 6 } & $A M S$ & $B I O$ & $R V S$ & $A M S$ & BIO & RVS \\
\hline 0 & $41.59^{\mathrm{a}}$ & $35.25^{\mathrm{A}}$ & $44.07^{\mathrm{a}}$ & $42.15^{\mathrm{e}}$ & $35.24^{\mathrm{E}}$ & $44.86^{\mathrm{e}}$ \\
2 & $33.03^{\mathrm{b}}$ & $34.40^{\mathrm{B}}$ & $41.54^{\mathrm{b}}$ & $32.70^{\mathrm{f}}$ & $32.87^{\mathrm{F}}$ & $41.86^{\mathrm{f}}$ \\
4 & $27.25^{\mathrm{c}}$ & $33.71^{\mathrm{C}}$ & $37.64^{\mathrm{c}}$ & $23.37^{\mathrm{g}}$ & $30.50^{\mathrm{G}}$ & $37.53^{\mathrm{g}}$ \\
6 & $23.48^{\mathrm{d}}$ & $33.02^{\mathrm{D}}$ & $34.22^{\mathrm{d}}$ & $20.24^{\mathrm{h}}$ & $27.50^{\mathrm{H}}$ & $32.34^{\mathrm{h}}$ \\
\hline
\end{tabular}

ร: Means with the same letter in the same column are not significantly different from each other for each column.

The gray shaded cells are the ones within the recommended range of 32-42 kPa by DIN ISO 5707 
This trend was observed in different studies. One of them is the study carried out by Haeussermann and Hartung (2010). In a field study, they investigated the amount of and variation at the teat-end vacuum during milking depending upon the milk flow rate.

Öz et al. (2010) used three different milking system to evaluate their preformances and one of them was BIO. From the study conducted they also concluded that teat-end vacuum in b-phase decreased with an increase in flow rate. At a flow rate of $4.8 \mathrm{~L}$ $\mathrm{min}^{-1}$, they obtained a teat-end vacuum of $32.6 \mathrm{kPa}$ in b-phase. This finding is supported with the the teat-end vacuum found in this study for $\mathrm{BIO}$ and it could be $33.43 \mathrm{kPa}$ at $4.8 \mathrm{~L} \mathrm{~min}^{-1}$ by linear interpolation for the teat-end vacuum between the flow rate 4 and $6 \mathrm{~L} \mathrm{~min}^{-1}$.

The results obtained for the teat-end vacuum from Duncan's multiple range tests for the milk tube diameter effect on teatend vacuum are tabulated in Table 6.

Table 6- The Duncan's multiple range test results ${ }^{\zeta}$ for the milk tube diameter on teat-end vacuum (kPa) in b and d-phase in different milking systems

\begin{tabular}{ccccccc}
\hline \multirow{2}{*}{$\begin{array}{c}\text { Milk tube diameter } \\
(\mathrm{mm})\end{array}$} & \multicolumn{3}{c}{ Teat-end vacuum in b-phase } & \multicolumn{3}{c}{ Teat-end vacuum in d-phase } \\
\cline { 2 - 6 } & $A M S$ & $B I O$ & $R V S$ & $A M S$ & $B I O$ & $R V S$ \\
\hline 10 & $31.45^{\mathrm{a}}$ & $34.18^{\mathrm{A}}$ & $40.15^{\mathrm{a}^{\mathrm{\prime}}}$ & $28.30^{\mathrm{e}}$ & $29.18^{\mathrm{E}}$ & $38.95^{\mathrm{e}^{\mathrm{y}}}$ \\
14 & $31.28^{\mathrm{a}}$ & $34.16^{\mathrm{A}}$ & $40.02^{\mathrm{a}}$ & $29.49^{\mathrm{f}}$ & $32.86^{\mathrm{F}}$ & $39.58^{\mathrm{f}^{\mathrm{f}}}$ \\
16 & $31.28^{\mathrm{a}}$ & $33.95^{\mathrm{B}}$ & $37.93^{\mathrm{b}}$ & $31.03^{\mathrm{g}}$ & $32.72^{\mathrm{F}}$ & $38.93^{\mathrm{e}^{\prime}}$ \\
\hline
\end{tabular}

5: Means with the same letter in the same column are not significantly different from each other for each column.

The gray shaded cells are the ones within the recommended range of $32-42 \mathrm{kPa}$ by DIN ISO 5707

It could be stated that the milk tube diameter does not affect the teat-end vacuum in b-phase for AMS while only 16 mm tube diameter is significant as compared to 10 and $14 \mathrm{~mm}$. The use of 10 and $14 \mathrm{~mm}$ tube diameter does not differ the teat-end vacuum for BIO and RVS in b-phase statistically. The milk tube diameter effect on teat-end vacuum values in d-phase is statistically significant for AMS once the tube diameter increases from 10 to $16 \mathrm{~mm}$. The teat-end vacuum in d-phase for 14 and $16 \mathrm{~mm}$ tube diameter is not statistically significant while the teat-end vacuum for $10 \mathrm{~mm}$ is the lowest. The teat-end vacuum for RVS as a result of using different tube diameters does not differ when the 10 and $16 \mathrm{~mm}$ tube diameters are used. Actually, the results from the Duncan's multiple range for the tube diameter should be evaluated based on the recommended diameters by the manufacturers and it should be reminded here that only BIO recommended $10 \mathrm{~mm}$ milk tube diameter while the other two manufacturers offer (AMS and RVS) the use of $16 \mathrm{~mm}$ milk tube diameter. It seems to be that the use of $14 \mathrm{~mm}$ milk tube diameter for BIO will provide better teat-end vacuum as compared to manufacturer's recommendation of $10 \mathrm{~mm}$. On the other hand, the use of $16 \mathrm{~mm}$ milk tube diameter is considered to be appropriate for AMS since the differences in mik tube diameter in b-phase are not statistically significant while the highest teat-end vacuum value in d-phase can be obtained if the milk tube diameter of $16 \mathrm{~mm}$ used as it is significantly different than 10 and $14 \mathrm{~mm}$. The appropriate milk tube diameter for RVS should be $14 \mathrm{~mm}$ when statistical differences in b and d-phase are examined. Hence, the recommended value by the company for RVS should be changed to $14 \mathrm{~mm}$ from $16 \mathrm{~mm}$. The Duncan's multiple range tests for vacuum fluctuations are given in Table 7 thru 9. The effect of tube connection type on vacuum fluctuations can be seen from Table 7. Based on the results in Table 7, the $\mathrm{Y}$ piece connection should be recommended AMS since the vacuum fluctuations in d-phase is the lowest and statistically different than the other two connection types while the difference between Y-piece and direct tube connection is not significant in bphase. The use of half-half tube connection results in the highest vacuum fluctuation in b-phase as compared to other two tube connections. The effects of flow rate as a result of Duncan's multiple range tests are given in Table 8. As seen from the table, vacuum fluctuation in both, $b$ and $d$-phase increases as the flow rate is increased.

Table 7- The Duncan's multiple range test results ${ }^{\zeta}$ for the effect of tube connection type on vacuum fluctuations (kPa) in $b$ and d-phase in different milking systems

\begin{tabular}{ccccccc}
\hline \multirow{2}{*}{ Tube connection type } & \multicolumn{2}{c}{ Vacuum fluctuation in b-phase } & \multicolumn{2}{c}{ Vacuum fluctuation in d-phase } \\
\cline { 2 - 6 } & $A M S$ & $B I O$ & $R V S$ & $A M S$ & $B I O$ & $R V S$ \\
\hline YP & $6.23^{\mathrm{a}}$ & $6.10^{\mathrm{A}}$ & $5.64^{\mathrm{a}^{\mathrm{\prime}}}$ & $4.31^{\mathrm{d}}$ & $4.02^{\mathrm{D}}$ & $3.86^{\mathrm{d}^{\prime}}$ \\
HH & $7.51^{\mathrm{b}}$ & $4.67^{\mathrm{B}}$ & $6.30^{\mathrm{b}^{\prime}}$ & $6.14^{\mathrm{e}}$ & $3.73^{\mathrm{D}}$ & $4.44^{\mathrm{e}^{\prime}}$ \\
DT & $6.48^{\mathrm{a}}$ & $4.51^{\mathrm{B}}$ & $6.25^{\mathrm{b}}$ & $5.29^{\mathrm{f}}$ & $3.94^{\mathrm{D}}$ & $4.48^{\mathrm{e}^{\prime}}$ \\
\hline
\end{tabular}

५: Means with the same letter in the same column are not significantly different from each other for each column. YP: Y piece; HH: half- half and DT: direct tube connection 
Table 8- The Duncan's multiple range test results ${ }^{\zeta}$ for the effect of different flow rates on vacuum fluctuations (kPa) in b and d-phase in different milking systems

\begin{tabular}{ccccccc}
\hline \multirow{2}{*}{ Flow rate } & \multicolumn{2}{c}{ Vacuum fluctuationin } & b-phase & \multicolumn{2}{c}{ Vacuum fluctuation in d-phase } \\
\cline { 2 - 6 } & $A M S$ & $B I O$ & $R V S$ & $A M S$ & BIO & RVS \\
\hline 0 & $1.27^{\mathrm{a}}$ & $1.51^{\mathrm{A}}$ & $1.21^{\mathrm{a}}$ & $0.91^{\mathrm{a}}$ & $1.06^{\mathrm{A}}$ & $0.74^{\mathrm{a}}$ \\
2 & $6.64^{\mathrm{b}}$ & $3.94^{\mathrm{B}}$ & $5.37^{\mathrm{b}}$ & $5.15^{\mathrm{b}}$ & $4.26^{\mathrm{B}}$ & $4.06^{\mathrm{b}}$ \\
4 & $9.03^{\mathrm{c}}$ & $6.42^{\mathrm{C}}$ & $8.32^{\mathrm{c}}$ & $7.37^{\mathrm{c}}$ & $4.37^{\mathrm{B}}$ & $6.07^{\mathrm{c}^{\prime}}$ \\
6 & $10.00^{\mathrm{d}}$ & $8.50^{\mathrm{D}}$ & $9.34^{\mathrm{d}}$ & $7.55^{\mathrm{c}}$ & $5.89^{\mathrm{C}}$ & $6.17^{\mathrm{c}}$ \\
\hline
\end{tabular}

$\zeta$ : Means with the same letter in the same column are not significantly different from each other for each column

Ströbel et al. (2011) as a results of using three different AMS system concluded that vacuum fluctuations were considerably higher in the tested AMSs as compared to modern conventional systems. The vacuum fluctuations in b-phase for all three AMS system ranged between 6.41 and $12.63 \mathrm{kPa}$ range while the fluctuations ranged between 5.69 and $19.23 \mathrm{kPa}$ at a flow rate of 4.8 $\mathrm{L} \mathrm{min}^{-1}$ in d-phase. Rasmussen et al. (2006) also found similar trend in the study conducted with three different of automatic milking systems. At a flow range of $0.2 \mathrm{~L} \mathrm{~min}^{-1}$ fluctuations increased from 11 to $20.5 \mathrm{kPa}$ for AMS system. For the other two systems fluctuations ranged between $15.6-23.3 \mathrm{kPa}$ and $18.7-35.5 \mathrm{kPa}$ and in both, the fluctuations increased with an increase in flow rate. In this study, the vacuum fluctuations in AMS are also found to be higher than BIO and RVS even though all of the systems achieve quarter individual milking.

The results from the Duncan's multiple range tests for the milk tube diameter effect on vacuum fluctuations in b and d-phase are tabulated in Table 9.

Table 9- The Duncan's multiple range test results ${ }^{\zeta}$ for the milk tube diameter on vacuum fluctuations (kPa) in b and d-phase in different milking systems

\begin{tabular}{ccccccc}
\hline \multirow{2}{*}{$\begin{array}{c}\text { Milk tube diameter } \\
(\mathrm{mm})\end{array}$} & \multicolumn{3}{c}{ Vacuum fluctuation in b-phase } & \multicolumn{3}{c}{ Vacuum fluctuation in d-phase } \\
\cline { 2 - 6 } & $A M S$ & $B I O$ & $R V S$ & $A M S$ & $B I O$ & $R V S$ \\
\hline 10 & $6.03^{\mathrm{a}}$ & $5.22^{\mathrm{A}}$ & $6.01^{\mathrm{a}^{\mathrm{a}}}$ & $5.59^{\mathrm{a}}$ & $5.79^{\mathrm{A}}$ & $4.40^{\mathrm{a}^{\mathrm{a}}}$ \\
14 & $6.91^{\mathrm{b}}$ & $5.01^{\mathrm{A}}$ & $6.08^{\mathrm{a}^{\mathrm{a}}}$ & $5.27^{\mathrm{ab}}$ & $3.00^{\mathrm{B}}$ & $4.19^{\mathrm{a}^{\mathrm{b}}}$ \\
16 & $7.27^{\mathrm{b}}$ & $5.04^{\mathrm{A}}$ & $6.09^{\mathrm{a}^{\mathrm{a}}}$ & $4.88^{\mathrm{b}}$ & $2.90^{\mathrm{B}}$ & $4.19^{\mathrm{a}^{\mathrm{a}}}$ \\
\hline
\end{tabular}

$\zeta$ : Means with the same letter in the same column are not significantly different from each other for each column

It seems to be that the use of 14 or $16 \mathrm{~mm}$ tube diameter instead of recommended tube diameter of $10 \mathrm{~mm}$ by BIO would be appropriate since the differences between 14 and $16 \mathrm{~mm}$ tube diameter in $\mathrm{b}$ and d-phase are insignificant but the highest fluctuations occur at $10 \mathrm{~mm}$ tube diameter and difference than the other two diameters are statistically significant. This finding supports the findings and recommendation of $14 \mathrm{~mm}$ tube diameter in terms of teat-end vacuum values as given in Table 6 . If the vacuum fluctuations are examined for AMS, it is seen that lowest ones are obtained at $10 \mathrm{~mm}$ in $\mathrm{b}$-phase and $16 \mathrm{~mm}$ for the d-phase. On the other hand, the differences in milk tube diameter are not statistically significant for the RVS teat cup. This means that any diameter can be used for RVS if the vacuum fluctuations are considered in $b$ and d-phase. The milk tube diameter for the RVS teat cup could be $14 \mathrm{~mm}$.

\section{Conclusions}

The following conclusions were drawn from the study conducted:

- The teat-end vacuum in BIO teat cup is always between the range of 32 and $42 \mathrm{kPa}$ as recommended by ISO at any flow and for all three types of connections.

- $\quad$ For RVS teat cup it could be stated that the teat-end vacuum is between 32-42 kPa range if the flow rate varies between 4 and $6 \mathrm{~L} \mathrm{~min}^{-1}$ for both direct and half-half connection while Y-piece connection meets ISO requirements if the flow rate changes between 2 and $6 \mathrm{~L} \mathrm{~min}^{-1}$.

- The teat-end vacuum for AMS is similar for all three types of connections. Only the flow rate that provides 32-42 kPa vacuum range is $2 \mathrm{~L} \mathrm{~min}^{-1}$ for direct tube and half and half connection. With the start of milk flow, the teat-end vacuum for AMS is beyond the recommended range by ISO if Y-piece connection is used at any diameter.

- $\quad$ The main effect of tube connection type (direct, half-half and Y piece) along with flow rate and milk tube inside diameter and their possible (double and triple) interactions are significant on teat-end vacuum at a probability level of $95 \%$. 
- As an opposite of teat-end vacuum evaluations, there are many insignificant factors that affect vacuum fluctuations in different milking systems. As main factors, the effects of tube connection type and flow rate on vacuum fluctuations are significant at a probability level of $95 \%$ except the tube connection type for BIO in d-phase.

- It seems to be that the use of 14 or $16 \mathrm{~mm}$ milk tube diameter for BIO will provide better teat-end vacuum as compared to manufacturer's recommendation of $10 \mathrm{~mm}$.

- The use of $16 \mathrm{~mm}$ milk tube diameter is considered to be appropriate for AMS and this was the recommended value by the manufacturer.

- The appropriate milk tube diameter for RVS should be $14 \mathrm{~mm}$ when statistical differences in b and d-phase are examined from the point of teat-end vacuum and vacuum fluctuations. Hence the recommended value for RVS should be changed to $14 \mathrm{~mm}$ from $16 \mathrm{~mm}$.

\section{References}

Besier J, Lind O and Bruckmaier R M (2016). Dynamics of teat-end vacuum during machine milking: types, causes and impacts on teat condition and udder health - a literature review. Journal of Applied Animal Research 44(1): $263-272$. https://doi.org/10.1080/09712119.2015.1031780

Bobić T, Andrašić D, Pero Mijić, Gregić M, Baban M. And Vesna Gantner V (2018). The effect of teat cup liner type on the teat condition of Holstein primiparous cows. Journal of Central European Agriculture 19(4):766-771. https://doi.org/10.5513/jcea01/19.4.2353

DIN ISO (2010a). International Organization for Standardization. DIN ISO 5707. Milking machine installations, construction and performance.

DIN ISO (2010b). International Organization for Standardization. DIN ISO 6690. Milking machine installations - mechanical tests. International Organization for Standardization

Graff K (2005). Untersuchungen von Zusammenhängen zwischen morphologischen Merkmalen des Euters, der Eutergesundheit und melktechnischen Parametern bei Tieren der Rasse Deutsches Holstein. Dissertation Martin-Luther-Universität, Halle Wittenberg, Germany

Haeussermann A \& Hartung E (2010). A Field Study on Teat-End Vacuum in Different Milking Systems and its Effect on Teat Condition. The First North American Conference on Precision Dairy Management 2010. Toronto-Ontario, Canada

Mein G A (1992). Action of the cluster during milking . In Machine Milking and Lactation, eds A. J. Bramley \& F. H. Dodd, Insight Books VT, USA: p.122-123

Nyhan J F (1968). Effect of vacuum fluctuation on udder disease. In: Proceedings of the Symposium on Machine Milking, Shinfield; p. 71-82

O'Callaghan E, O'Shea J, Meaney W J, Crowley C (1976). Effect of milking machine vacuum fluctuations and liner slip on bovine mastitis infectivity. Irish Journal of Agricultural Research 15(3):401-418

Ordolff D (1991). Melkzeuge und deren Eigenschaften aus der Sicht der Praxis. Milchpraxis 29 (2): 216-220

O'Shea J, O'Callaghan E, Meaney W J, Crowley C (1976). Effect of combinations of large and small irregular and cyclic vacuum fluctuations in the milking machine on the rate of new udder infection in dairy cows. Irish Journal of Agricultural Research 15(3):377-399

Öz H, Meierhöfer S R, Ströbel U, Ammon C (2010). Comparison of the Vacuum Dynamics of Conventional and Quarter Individual Milking Systems. Journal of Agricultural Sciences 16(2010): 162-168

Rasmussen M D, Wiking L, Bjerring M, and Larsen H C (2006). Influence of Air Intake on the Concentration of Free Fatty Acids and Vacuum Fluctuations During Automatic Milking. Journal of Dairy Science 89:4596-4605. https://doi.org/10.3168/jds.S0022-0302(06)72509-7

Rose S (2006). Untersuchung mechanischer Belastungen am Euter bei verschiedenen Melksystemen (Evaluation of mechanic forces on the udder with different milking systems). Dissertation, Berlin, Germany. Forschungsbericht Agrartechnik des Arbeitskreises Forschung und Lehre der Max-Eyth-Gesellschaft Agrartechnik im VDI (VDI-MEG) Nr. 436. Eigenverlag, Berlin

Ströbel U, Meierhöfer S R, Öz H, Entorf A C, Popp L, Brunsch R (2011). Analysis and evaluation of the teat-end vacuum condition in different automatic milking systems. Irish Journal of Agricultural and Food Research 50: 209-221

Ströbel U (2012). Development of an Online Analysis and Control System for Individual Quarter Milking Systems, Dissertation, Berlin, Germany

Thiel C C, Cousins C L, Westgarth D R, Neave F K (1973). The influence of some physical characteristics of milking machine on the rate of new mastitis infections. Journal of Dairy Research 40 (1):117-120

Tolle A, Heeschen W, Hamann J (1977). Grundlagen einer systematischen bekämpfung der subklinischen mastitis des rindes. Kieler Milchwirtschaftliche Forschungsberichte (Jg. 29, Nr. 1)

(C) 2022 by the author(s). Published by Ankara University, Faculty of Agriculture, Ankara, Turkey. This is an Open Access article distributed under the terms and conditions of the Creative Commons Attribution (CC BY) license (http://creativecommons.org/licenses/by/4.0/), which permits unrestricted use, distribution, and reproduction in any medium, provided the original work is properly cited. 